Article

\title{
Key Barriers to the Adoption of Biomass Gasification in Burkina Faso
}

\author{
Fanta Barry ${ }^{1,2, * \mathbb{D}}$, Marie Sawadogo ${ }^{1} \mathbb{D}$, Maïmouna Bologo (Traoré) ${ }^{3}$, Igor W. K. Ouédraogo ${ }^{1}$ and $^{\text {Thomas Dogot }}{ }^{2}$ \\ 1 Laboratory of Renewable Energy and Energy Efficiency (LabEREE), International Institute of Water and \\ Environmental Engineering (Institute 2iE), Ouagadougou 01 BP 594, Burkina Faso; \\ marie.sawadogo@2ie-edu.org (M.S.); igor.ouedraogo@2ie-edu.org (I.W.K.O.) \\ 2 Department of Economic and Rural Development, Gembloux Agro Bio-Tech, University of Liège, \\ 5030 Gembloux, Belgium; Thomas.dogot@uliege.be \\ 3 Department of Human, Social and Managerial Sciences (SHSM), International Institute of Water and \\ Environmental Engineering (Institute 2iE), Ouagadougou 01 BP 594, Burkina Faso; \\ maimouna.bologo@2ie-edu.org \\ * Correspondence: fanta.barry@2ie-edu.org or fanta.barry@doct.uliege.be or barryfanta2002@yahoo.fr
}

Citation: Barry, F.; Sawadogo, M.; Bologo (Traoré), M.; Ouédraogo, I.W.K.; Dogot, T. Key Barriers to the Adoption of Biomass Gasification in Burkina Faso. Sustainability 2021, 13, 7324. https://doi.org/10.3390/ su13137324

Academic Editor: Dino Musmarra

Received: 6 May 2021

Accepted: 25 June 2021

Published: 30 June 2021

Publisher's Note: MDPI stays neutral with regard to jurisdictional claims in published maps and institutional affiliations.

Copyright: (c) 2021 by the authors. Licensee MDPI, Basel, Switzerland. This article is an open access article distributed under the terms and conditions of the Creative Commons Attribution (CC BY) license (https:/ / creativecommons.org/licenses/by/ $4.0 /)$.

\begin{abstract}
The industrial sector in Burkina Faso faces two significant energy challenges access to efficient energy sources that are also renewable. Pyrolysis and gasification are emerging as conversion pathways that exploit available agricultural and industrial biomass. Pyrolysis has been adopted successfully, whereas gasification failed without getting beyond the experimental stage. This article assesses potential barriers to the adoption of gasification based on interviews with the stakeholders of the energy sector (users, NGOs, policy makers). We use pyrolysis as a benchmark to point out the barriers to adoption. The hierarchical analysis process (AHP) method was applied to identify the most significant barriers to the adoption of gasification. Twenty-seven barriers were identified and prioritized in two dimensions and five categories "technical", "economic and financial", "socio-cultural and organizational", "political, governmental and institutional", and "ecological and geographical" barriers. The category of socio-cultural and organizational barriers emerged as the most critical in the adoption of gasification. This category deserves special consideration to go past the pilot installation stage and adopting this technology.
\end{abstract}

Keywords: socio-cultural lock-in; Analytical Hierarchical Process (AHP), adoption barriers; biomass gasification; Burkina Faso

\section{Introduction}

\subsection{Biomass as a Source of Energy for Agro-Industry in Developing Countries}

Fossil fuels are still the world's most widely used energy source, accounting for more than $80 \%$ of primary energy consumption [1]. However, they are sources that emit large amount of $\mathrm{CO}_{2}$, emission that has environmental impacts in terms of global warming [2]. With growing concerns about greenhouse gas emissions and climate change associated with the growing scarcity of fossil fuels, renewable energy sources are becoming essential for the world's energy production $[3,4]$. Biomass is widely used in traditional industries and rural households in most developing countries [5]. Various kinds of biomass are possible and their conversion pathways must be improved. If lignocellulosic biomass is suitable for thermochemical recovery, the organic fraction of municipal solid waste is mainly treated by composting or anaerobic digestion [6]. In Africa, the main source of biomass is wood, and in 2010 the total forest stock was 7130 billion tons, but the amount available each year without incurring the risk of deforestation is lower [7]. Forest areas are constantly decreasing due to strong anthropic pressure. Forest cover in the Sahelian region decreased from 11.4 million hectares in 2010 to 3.9 million hectares in 2017, i.e., an average decrease of about $66 \%$ [8]. Given the sustainability constraints associated with 
the use of firewood, agricultural by-products and waste are used to produce energy for industry. The main tropical crops that provide residues or waste are rice, sugar cane, and cotton [9]. Most developing countries use rice husks as an energy source to parboil paddy rice [10]. Additionally to the use of rice husks, the industries in Burkina Faso use locally available cashew nut shells as a substitute to firewood [2].

\subsection{Gasification and Pyrolysis Are Eco-Friendly and Efficient Routes for Lignocellulosic Biomass Conversion}

Biomass can be converted into high-value primary and end products in solid, liquid or gaseous form using thermochemical conversion technologies [11]. Direct combustion is often used to meet the heat and steam needs of traditional industries. However, it releases particulate and gaseous pollutants harmful to human health and the climate [12]. Mixing of various fuels, such as coal and torrefied biomass, can reduce gas emissions, but the ash problems remain [13]. Gasification and pyrolysis are environmentally eco-friendly and efficient ways of converting lignocellulosic biomass to direct combustion [14]. Both processes have certain advantages in terms of energy efficiency. The products are more sustainable and suited to the bioenergy needs of traditional industries. Gasification is a process for the thermal conversion of carbon-based solids (coal, wood, straw, etc.) into synthesis gas or syngas, which is composed of hydrogen $\left(\mathrm{H}_{2}\right)$, carbon monoxide $(\mathrm{CO})$, carbon dioxide $\left(\mathrm{CO}_{2}\right)$ and methane $\left(\mathrm{CH}_{4}\right)$ [15]. Syngas is usually used to produce electricity, heat, or chemicals such as methanol and hydrogen [16]. The transformation takes place under the effect of a gasification agent (air, oxygen, steam) added in controlled quantities, usually with air flow rate between $10 \mathrm{~L} / \mathrm{min}$ to $30 \mathrm{~L} / \mathrm{min}$ and temperatures ranging from $500{ }^{\circ} \mathrm{C}$ to $1000{ }^{\circ} \mathrm{C}$ [17]. Gasification can therefore be considered as optimization of pyrolysis aimed at increasing the yield of gas. Replacing air with oxygen as a gasification agent eliminates nitrogen. This favors the production of high calorific value gases. Heating rate, reactor design, and gas after-treatment are the main factors that control the production of clean, high-quality gas products from gasification [18]. Pyrolysis is the thermal decomposition of organic matter without oxygen or any other reagent to produce coal, a liquid fraction, and gases such as hydrogen, carbon monoxide and dioxide, and methane. Pyrolysis is carried out at temperatures ranging from $400{ }^{\circ} \mathrm{C}$ to $760{ }^{\circ} \mathrm{C}$ [19]. At these moderate temperatures, two types of pyrolysis can be distinguished depending on the residence time. When the residence time is very short, pyrolysis is called fast pyrolysis and improves the liquid yield. With a low heating rate, a longer vapor residence time, and a moderate temperature, slow pyrolysis mainly produces charcoal [18].

\subsection{Adoption Issue of Biomass Thermochemical Conversion Technologies}

The two technologies recently re-emerged due to environmental concerns and their ability to exploit available biomass. Both technologies are used in several countries including the United Kingdom, Australia, China, India, Singapore, Uganda, and Mali [20,21], but their use is limited for different reasons. In China, Zang and coll. [22] found the key factor in the development and marketing of gasification is its economic advantage, which depends on the initial investment, annual operating cost, management, and official policies. The initial investment cost includes the cost of site construction, a biomass preparation unit, a gasification reactor, a modified generator, a power grid and subsidies for the diffusion and marketing of the technology $[17,20]$. Financial barriers concern high initial investment, maintenance, and research costs [23]. A subsidy that is too small cannot bridge the gap between financial support and the cost of production, leaving projects short of funds [24]. Africa cannot provide lucrative market conditions for the successful commercialization of gasification technology due to sparse rural living conditions. For example, generating electricity on a household scale depends on the availability of biomass and population size. The application of the technology may have barriers such as technical, economic, financial, and political [23]. Technical barriers include parameters such as the temperature of the gasification reaction [25], the moisture content of the biomass, which should generally be below $15 \%$ [26], and the presence of tars in the resulting synthesis gas, which has contributed to 
the instability of the technology [27]. Non-technical barriers include institutional, financial, political, and market barriers, lack of knowledge about biomass resources and the implications of global warming, the lack of energy policies and regulatory frameworks to encourage distributed generation, and the lack of regulatory frameworks related to technical requirements [28]. The so-called institutional barriers are usually delays in the operationalization of the bioenergy program caused by scheduling problems. Informational barriers are mainly related to the level of knowledge of gasification technology. Lack of information on biomass characterization and processing techniques, the maintenance and operating costs of the technology, and lack of user training limit its long-term acceptance. Although these barriers are widely addressed in the literature, investigations into the role the barriers play in preventing the adoption of gasification are lacking. This paper aims to fill this gap by analyzing the main barriers to gasification adoption, using the success of pyrolysis as a benchmark to learn from its diffusion and adoption process.

\section{Materials and Methods}

\subsection{Case Studies of Gasification in Burkina Faso}

Some gasification plants have been installed in Burkina Faso by non-governmental and research organizations $[29,30]$. These plants have been implemented to produce thermal and electrical energy from biomass. The types of biomasses used are stalks of millet, sorghum, maize, cotton, rice husks and groundnut shells. In 2009, the German NGO «Atmosfair» (Berlin, Germany), installed $22 \mathrm{kWe}$ Indian power generation technology in the village of Po. This gas generator was intended to supply electricity to the community Health District based on the conversion of cotton stalks, maize, sorghum, and groundnut husks. In 2012, the Burkinabe company «ISOMET» supported by Netherlands Development Organization (SNV), had installed gasification for the cashew nut producers' group «WOUOL» (Dakoro, Niger). The 40-kW unit allows the steam production to process cashew nuts, thereby making use of production residues instead of wood, as was previously the case. In 2013, two types of rice husk gasification, one locally made for heat production and the other imported from India for electricity production, were installed in Dano for the NGO «DREYER». In 2015, the same types of gas generators were implemented for the Union of Rice Parboiler Associations of Bama by SNV funded by the Taiwanese cooperation agency.

In 2012, a small-scale gasifier intended solely for the production of heat by combustion of the syngas was installed on the research platform of LabEREE at Institute 2iE in Burkina Faso. In addition, the Institute for Research in Applied Sciences and Technologies (IRSAT) has developed gasification projects for parboiling rice in the village of Bagre in collaboration with OXFAM.

None of the gasification case studies tested in the field were successful. To identify the different barriers to the technology, qualitative information was collected from stakeholders in case studies in three rural townships in Po, Dano and Bama, Burkina Faso.

\subsection{Case Studies of Pyrolysis in Burkina Faso: Reference Benchmark}

Benchmarking is defined in different ways depending on the field of application. However, Rank Xerox, the founder of this concept, defined benchmarking as "a continuous and systematic process of measuring performance, products, methods and services against those of the most serious competitors and companies recognized as world leaders to ensure superiority" [31]. Benchmarking can help understand the failure of gasification by comparing it with the success of pyrolysis. Since 2015, pyrolysis facilities have been installed in more than six cashew processing and mango drying plants in Burkina Faso. They were designed to produce thermal energy from waste (cashew shells) and reduce waste produced by these factories by at least a third using an environmentally friendly approach. The system can operate independently from the power grid. 


\subsection{Data Collection}

Data were collected through a literature review and semi-structured interviews with gasification stakeholders (NGO managers, paddy rice processors, millers, technicians, and private companies). In addition, data on pyrolysis benchmarking were collected from oil mill managers and cashew nut processors. The information focused on the context of installed technologies, their advantages, and the barriers to their adoption.

\subsection{Analytic Hierarchy Process (AHP) Method}

AHP was used to rank obstacles to the adoption of biomass gasification thanks to its mathematical simplicity and flexibility [32]. Used alone or combined with other methods, it is one of the preferred research tools in several decision-making areas [33,34].

For instance, AHP has been widely used in the field of renewable energy. Recently, AHP was used to prioritize the main barriers to the use of renewable energy-based minigrids in Ghana [35] and Myanmar [36], for the development of renewable energy that can fill the electricity gap in Kazakhstan [37], the acceptability of renewable energy technologies in Nepal [38] and in Indian [39]. AHP compares the criteria in pairs according to a hierarchical structure at several levels $[40,41]$ and constructs a set of pairwise comparison matrices to determine the weights of the barriers.

In the present study, the pairwise comparison matrices of the categories and subcategories of barriers were constructed either by simulation or by collecting stakeholder opinions using a participatory approach. In this article, the collected information is simulated for each category of barriers and each subcategory of barriers according to a nine-point scale, called the Saaty scale (Table 1).

Table 1. Saaty scale.

\begin{tabular}{cc}
\hline Weight or Intensity of the Comparison & Verbal Judgment of Preference \\
\hline 1 & Equal importance \\
2 & Weak or slight \\
3 & Moderate importance \\
4 & Moderate plus \\
5 & Strong importance \\
6 & Strong plus \\
7 & Very strong importance \\
8 & Very, very strong \\
9 & Extreme importance \\
\hline
\end{tabular}

The relative importance of a component or criterion $i$ with respect to component $\mathrm{j}$ is assessed using the Saaty scale and assigned to the $(i, j)$ th position of the pairwise comparison matrix. The inverse of the assigned judgment is automatically associated with the $(j, i)$ th position. The diagonal elements of the matrix are equal 1 . Thus, the comparison matrix is formed according to the following rule [42]:

$$
\text { aij }>0 ; \text { aji }=1 / \text { aij and aii }=1 Y i \text {. }
$$

The judgments were combined by applying the geometric mean to form the matrix of the comparison judgments. After constructing the comparison matrix in pairs, we used its eigenvalues to select the highest one or the associated eigenvector. The terms of this column matrix constitute the weights or importance coefficients of the various criteria. The weights for each category were calculated using Equation (1):

$$
\mathrm{Aw}=\lambda \max * \mathrm{w}
$$

where $\mathrm{A}=$ the square matrix resulting from the comparison by pairs of size $\mathrm{n} \times \mathrm{n}$, for $\mathrm{n}$ criteria; $\mathrm{w}=$ the eigen vector or priority vector of size $\mathrm{n} \times 1$, or weight; $\lambda \max =$ the maximum eigen value. 
The eigen value and priority vector can be obtained by solving the eigen vector principle. However, the priority vector can be solved in different ways. In this paper, the priorities were obtained by normalizing the geometric means of the lines.

In this hierarchical approach, it is also possible to check the consistency of comparison of the barriers by calculating the consistency or coherence ratio (CR). The CR is an acceptance test of the weights of the different barriers. This step aims to detect possible inconsistencies in the comparison of the importance of each pair of barriers. The consistency ratio $\mathrm{CR}$ is calculated by dividing the consistency index (CI) by the randomized index (RI) as in Equation (2). Then, the consistency index is calculated using Equation (3). The randomized index depends on the size of the matrix or the number of barriers considered (Table 2).

$$
\begin{gathered}
C R=C I / R I, \\
C I=(\lambda \max -n) /(n-1)
\end{gathered}
$$

Table 2. Value of the randomized index as a function of the size of the matrix [43].

\begin{tabular}{ccccccccc}
\hline Matrix size & $\mathbf{3}$ & $\mathbf{4}$ & $\mathbf{5}$ & $\mathbf{6}$ & $\mathbf{7}$ & $\mathbf{8}$ & $\mathbf{9}$ & $\mathbf{1 0}$ \\
\hline RI & 0.58 & 0.90 & 1.12 & 1.24 & 1.32 & 1.41 & 1.45 & 1.49 \\
\hline
\end{tabular}

The value of the ratio varies with the size of the matrix. With matrices larger than 5 , judgments of the criteria become difficult. For the consistency of comparative judgments to be acceptable, the $\mathrm{CR}$ ratio should normally be less than or close to 0.2 [44]. Some authors have considered a ratio of at most 0.1 [39] and others 0.2 [36,45]. In this article, we consider a ratio of 0.2 .

\section{Results}

\subsection{Typology of Barriers to the Adoption of Gasification}

The hierarchical structure of the barriers was established by classifying them according to three levels of dimensions, categories and subcategories. Twenty-seven barriers likely to block the adoption of gasification were identified in our study context. These barriers were classified into five categories: technical, economic and financial, socio-cultural and organizational, governmental and institutional policy, and ecological and geographical barriers (Figure 1).

\subsubsection{Technical Barriers}

In Burkina Faso, gasification is still in its infancy. According to stakeholders, most of the installed technologies became defective one year after installation, or even earlier, after only three months of use. This situation is partly linked to the large size of the gasification equipment (F1), the problem of dimensioning the equipment about the real needs of the users (F2) and the lack of spare parts at local and national level (F3). The large size of the gasifier makes it a complex and challenging technology to set up. The problem of dimensioning the equipment about the users' needs influences the quantity of energy produced and the expected production capacity. The incompatibility of the new technology with user expectations and the difficulty of obtaining spare parts (batteries and spark plugs) have harmed its adoption.

\subsubsection{Economic and Financial Barriers}

An important initial investment is usually required for the development of technologies. A significant investment is commonly a challenge given factors such as lack of funding and government policies [23]. Economic and financial barriers have also contributed to the failure of gasification. This technology, which is imported from industrialized countries, is more expensive than local technologies. The initial cost (F4) of the technologies installed in Burkina Faso is very high. However, it does not seem to be a determining barrier in its 
adoption, given the subsidies provided by donors. However, the high cost of spare parts (F5), the lack of a financing mechanism (F6), absence of subsidies (F7), its lower profitability compared to older technologies (F8), insufficient financial resources for investment (F9), the time needed (minimum $4 \mathrm{~h}$ ) to operate the gas generators (F10) and the competitive price of other energy sources (F11) have helped discourage actors.

\begin{tabular}{|c|c|c|c|c|c|c|}
\hline \multicolumn{7}{|c|}{ Identification of the key barriers gasification adoption } \\
\hline \multicolumn{3}{|c|}{ Intrinsic barriers } & \multicolumn{4}{|c|}{ Extrinsic barriers } \\
\hline & $\nabla$ & 7 & & $\nabla$ & 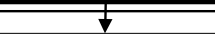 & 7 \\
\hline \multicolumn{2}{|c|}{ Technical barriers } & $\begin{array}{l}\text { Economic and } \\
\text { financial barriers }\end{array}$ & $\begin{array}{l}\text { Socio } \\
\text { orgaa } \\
\text { barri }\end{array}$ & $\begin{array}{l}\text { ultural and } \\
\text { zational } \\
\text { s }\end{array}$ & $\begin{array}{l}\text { Political, } \\
\text { governmental, } \\
\text { Institutional barriers }\end{array}$ & $\begin{array}{l}\text { Ecological and } \\
\text { geographical } \\
\text { barriers }\end{array}$ \\
\hline & $\mathrm{F}_{1} \cdot \mathrm{F}_{2} \cdot \mathrm{F}_{3}$ & $\mathrm{~F}_{4}, \mathrm{~F}_{5}, \mathrm{~F}_{6}, \mathrm{~F}_{7} ; \mathrm{F}_{8} ; \mathrm{F}_{9}, \mathrm{~F}_{10}$ & \multicolumn{2}{|c|}{$\mathrm{F}_{12 ;} \mathrm{F}_{13 ;} \mathrm{F}_{14}, \mathrm{~F}_{15 ;} \mathrm{F}_{16}$} & $\mathrm{~F}_{17} ; \mathrm{F}_{18} ; \mathrm{F}_{19} ; \mathrm{F}_{20} ; \mathrm{F}_{21} ; \mathrm{F}_{22}$ & $\mathrm{~F}_{24 ;} \mathrm{F}_{25 ;} \mathrm{F}_{26 ;} \mathrm{F}_{27}$ \\
\hline F1 & Large size & echnology & F15 & \multicolumn{3}{|c|}{ Insufficient user training } \\
\hline F2 & Equipmen & ing problem & F16 & \multicolumn{3}{|c|}{ Lack of stakeholder involvement and coordination } \\
\hline F3 & $\begin{array}{l}\text { Lack of sp } \\
\text { national le }\end{array}$ & parts at local and & F17 & \multicolumn{3}{|c|}{ Lack of political commitment } \\
\hline F4 & High initi & vestment costs & F18 & \multicolumn{3}{|c|}{ Lack of adequate government support policy } \\
\hline F5 & High cost & bare parts & F19 & \multicolumn{3}{|c|}{ Lack of institutional, legal and regulatory framework } \\
\hline F6 & Lack of fu & g mechanism & F20 & \multicolumn{3}{|c|}{ Political instability } \\
\hline F7 & No subsid & & F21 & \multicolumn{3}{|c|}{ Lack of promotion and interest by the government } \\
\hline F8 & $\begin{array}{l}\text { Low profi } \\
\text { technique }\end{array}$ & ity compared to old & F22 & \multicolumn{3}{|c|}{ Lack of subsidy for biomass energy } \\
\hline F9 & $\begin{array}{l}\text { Insufficier } \\
\text { invest }\end{array}$ & ancial resources to & F23 & \multicolumn{3}{|c|}{ Political affiliation of actors in gasification projects } \\
\hline F10 & High payb & time & F24 & \multicolumn{3}{|c|}{ Biomass unavailability } \\
\hline F11 & $\begin{array}{l}\text { Competiti } \\
\text { sources }\end{array}$ & rice of other energy & F25 & \multicolumn{3}{|c|}{ Accessibility of biomass collection sites } \\
\hline F12 & Lack of ex & ence in gasification & F26 & \multicolumn{3}{|c|}{ Non-industrial means of transporting biomass } \\
\hline F13 & Lack of us & wareness & F27 & \multicolumn{3}{|c|}{$\begin{array}{l}\text { Access to electricity in the location hosting the } \\
\text { technology }\end{array}$} \\
\hline F14 & $\begin{array}{l}\text { Technolog } \\
\text { beneficiar }\end{array}$ & isuitable for some & & & & \\
\hline
\end{tabular}

Figure 1. Hierarchical structure of gasification adoption barriers in Burkina Faso.

\subsubsection{Socio-Cultural and Organizational Barriers}

Socio-cultural and organizational barriers include the lack of successful gasification experience (F12), lack of awareness among beneficiaries (F13), the fact the technology is not suitable for some beneficiaries (F14), insufficient training of users (F15), and lack of involvement and coordination between the different stakeholders (F16). The lack of information on the operation and management of the technology has made it difficult to set up, start, maintain and service the gas generators. Consequently, some parts (engines, batteries, etc.) have had a breakdown. In addition, their unavailability and inaccessibility on the local market have been a veritable barrier to the adoption of gasification. The lack of involvement and coordination between the different stakeholders (F16) prevented transparency in communication between the actors and led to a breakdown in trust. The non-involvement of key actors after the technology installation project was launched weakened the links between actors. Suspicion and trust lack set in between actors. This led to reluctance or resistance to the idea of adopting the technology. The state of mind led to a boycott of the organization and scheduling of work and ultimately to the failure of the technology. The proven unreliability of gasification (F12), the users' lack of awareness (F13), benefits and the lack of gender sensitivity (F14), have also been real barriers to the technology adoption. 


\subsubsection{Political, Governmental, Institutional Barriers}

Burkina Faso's renewable energy program has been characterized by a notable lack of political commitment to, promotion of, and interest in these promising technologies. This prevents the adoption of gasification. In addition, no subsidy mechanism is available for biomass energy and even less for gasification technologies. However, better access to financial incentives in different forms (subsidy, low-interest loans, long-term credit, etc.) could improve the financial viability of technologies and the affordability of services [46]. Recently, interest in renewable energy was promoted by giving civil servants access to credit for the purchase of solar panels. The lack of certification of manufacturers of the equipment does not guarantee that the operation complies with local legislation. The political instability linked to the insurrection, the transition and the attempted coup have tended to block the continuity and application of regulatory and legal texts. Beyond government actions, the political affiliation of the project actors has hindered their success. Every development project is a center of interest for specific categories of actors. The project thus appears to be a system of resources and opportunities that everyone tries to appropriate in their own way. For example, an individual's membership of a political party may hinder negotiations to ensure the sustainability of a given technology.

\subsubsection{Ecological and Geographical Barriers}

Ecological and geographical barriers are crucial aspects for the functioning of renewable energy technologies. The biomass availability (F24) is determined by the quantities allocated to competitive uses such as land fertility conservation, domestic use and animal feed. Availability of biomass is crucial for the uptake of gasification. Its disruption could prevent the exploitation of the technology for an extended moment and consequently reduce profits. For example, lack of feedstock contributed to the abandonment of a biomass gasification project as had already occurred in India [39]. Accessibility of biomass collection sites (F25) and non-industrial means of biomass transport (F26) are geographical barriers to the lack of paved roads, distance to collection points, and non-industrial means of transport such as mopeds, carts, and tricycles. Electricity access (F27) in the new technology site can also be a barrier to adopting gasification technology.

\subsection{Hierarchy of Barriers Subcategories}

The prioritization of barrier subcategories within each barrier category was made possible using AHP. The different components of each barrier category were classified according to their relative weight (Figures 2-6).

Analysis of Figure 2 suggests that within the category of technical barriers, the lack of spare parts at the local and national level $(57.36 \%)$ is the most decisive barrier to the adoption of gasification followed by the problem of dimensioning the equipment in relation to the real needs of users with a weighting of $28.65 \%$.

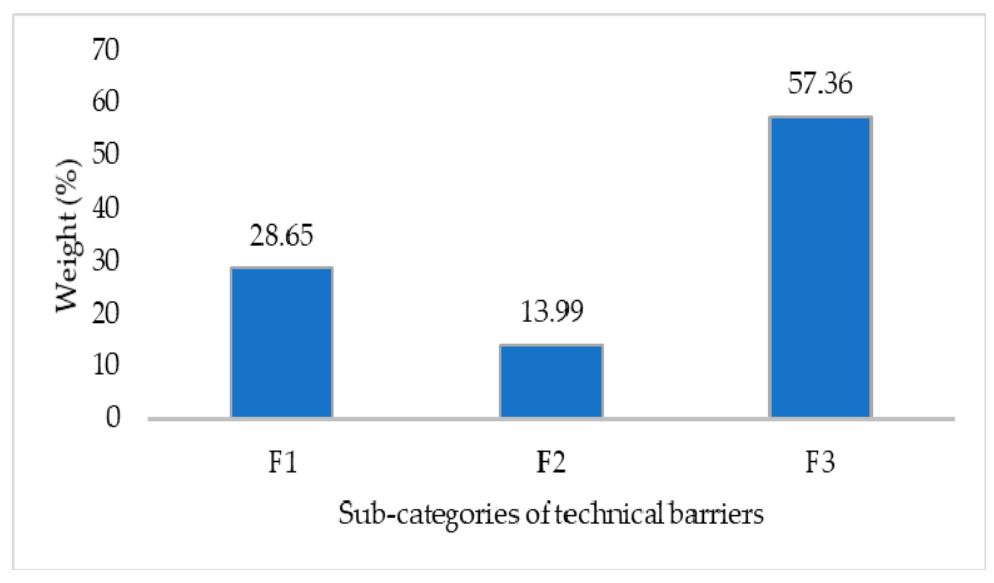

Figure 2. Weighting of the subcategories of technical barriers. 
Figure 3 shows that among economic and financial factors, the profitability of the technology compared to the past practices $(20.10 \%)$, the high payback time $(16.46 \%)$ and the lack of a financing mechanism (14.52\%) are the factors that determine the adoption of gasification.

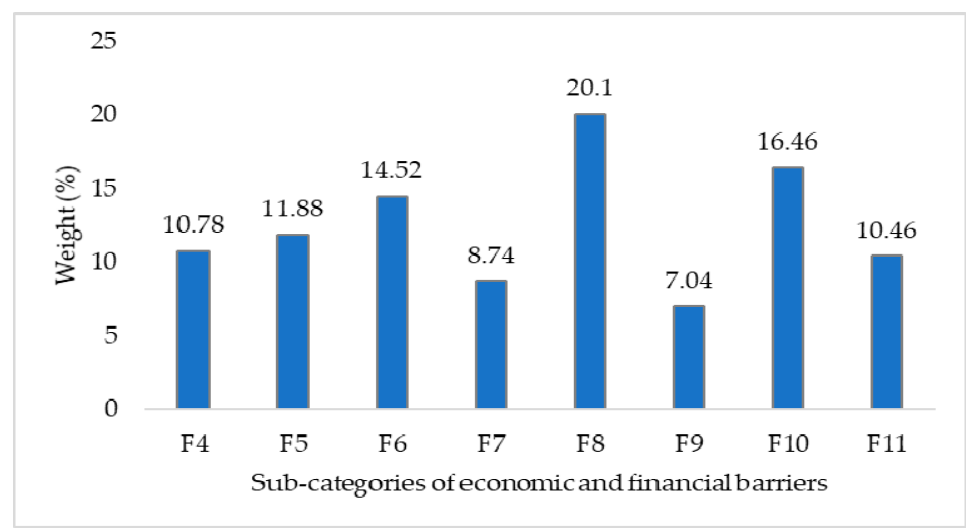

Figure 3. Weighting of the subcategories of economic and financial barriers.

Figure 4, which corresponds to the prioritization of socio-cultural and organizational barriers, shows that insufficient training of technology users ranks first $(29.4 \%)$, followed by the non-involvement of key actors $(22.74 \%)$, lack of coordination between stakeholders $(20.43 \%)$, and lack of successful experience $(17.07 \%)$.

Among the subcategories of governmental and institutional policy barriers (Figure 5), lack of subsidies, interest and promotion, political stability, which would help promote the technology, are the main barriers to the technology adoption.

The weighting of the ecological and geographical subcategories reveals that biomass availability $(38.75 \%)$, and access to electricity $(30.41 \%)$ are the two main barriers to the adoption of gasification (Figure 6).

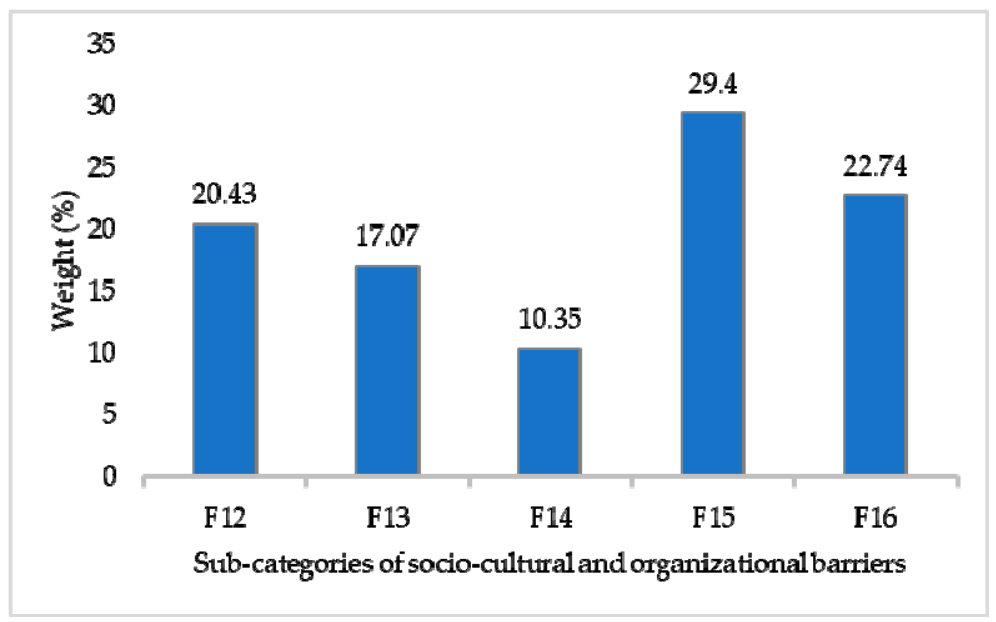

Figure 4. Weighting of the subcategories of socio-cultural and organizational barriers. 


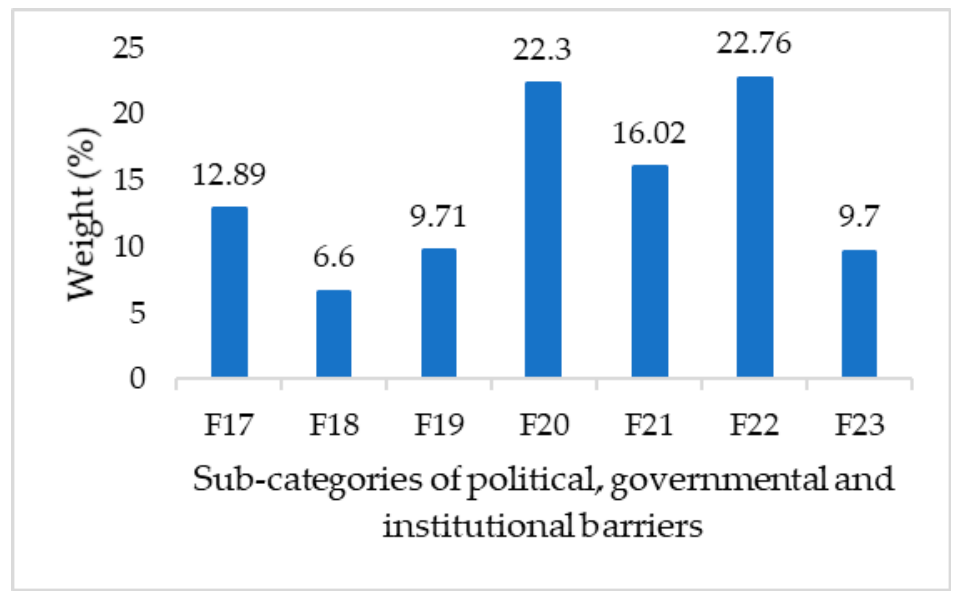

Figure 5. Weighting of the subcategories of political, governmental, and institutional barriers.

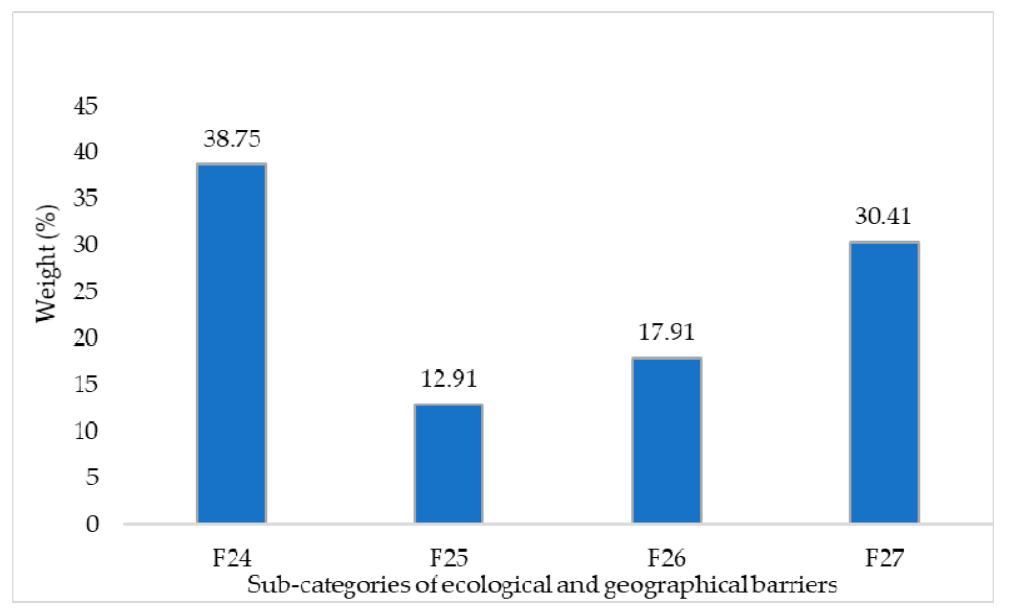

Figure 6. Weighting of the subcategories of ecological and geographical barriers.

The different categories of technical (T), economic and financial (EF), socio-cultural and organizational (SCO), governmental and institutional policy (GIP), and ecological and geographical (EG) barriers were assessed by the stakeholders (Figure 7).

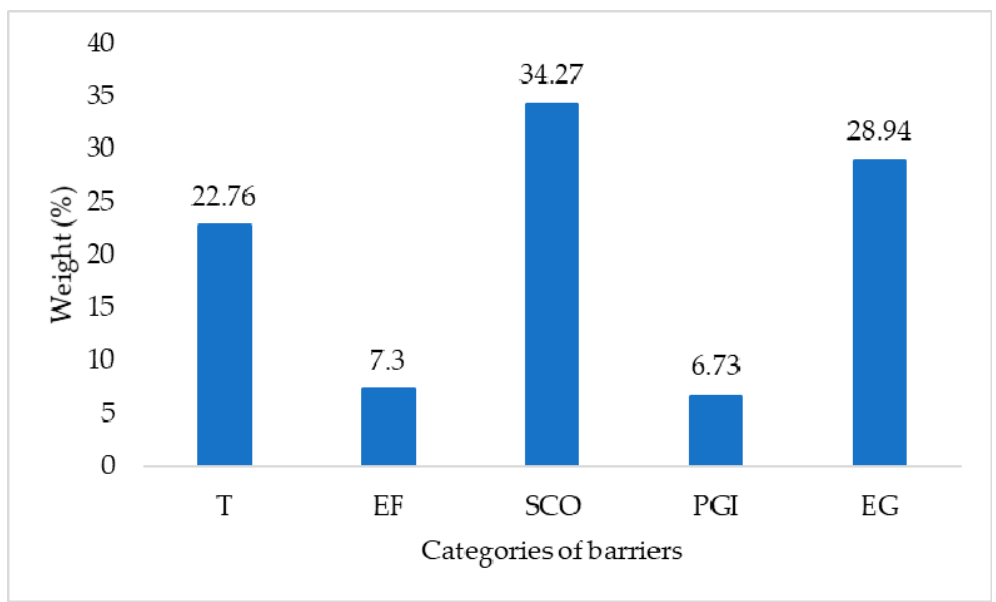

Figure 7. Classification of different categories of barriers to gasification adoption. 
The analyses show that socio-cultural and organizational barriers ranked first with a weighting of $34.27 \%$, followed by ecological and geographical barriers (28.94\%) and technical barriers (22.76\%).

A general classification of the key barriers of gasification adoption was undertaken based on their total weights. These weights were determined by multiplying the overall weight of each barrier category and the local weights of each of the specific barrier subcategories (Figure 8).

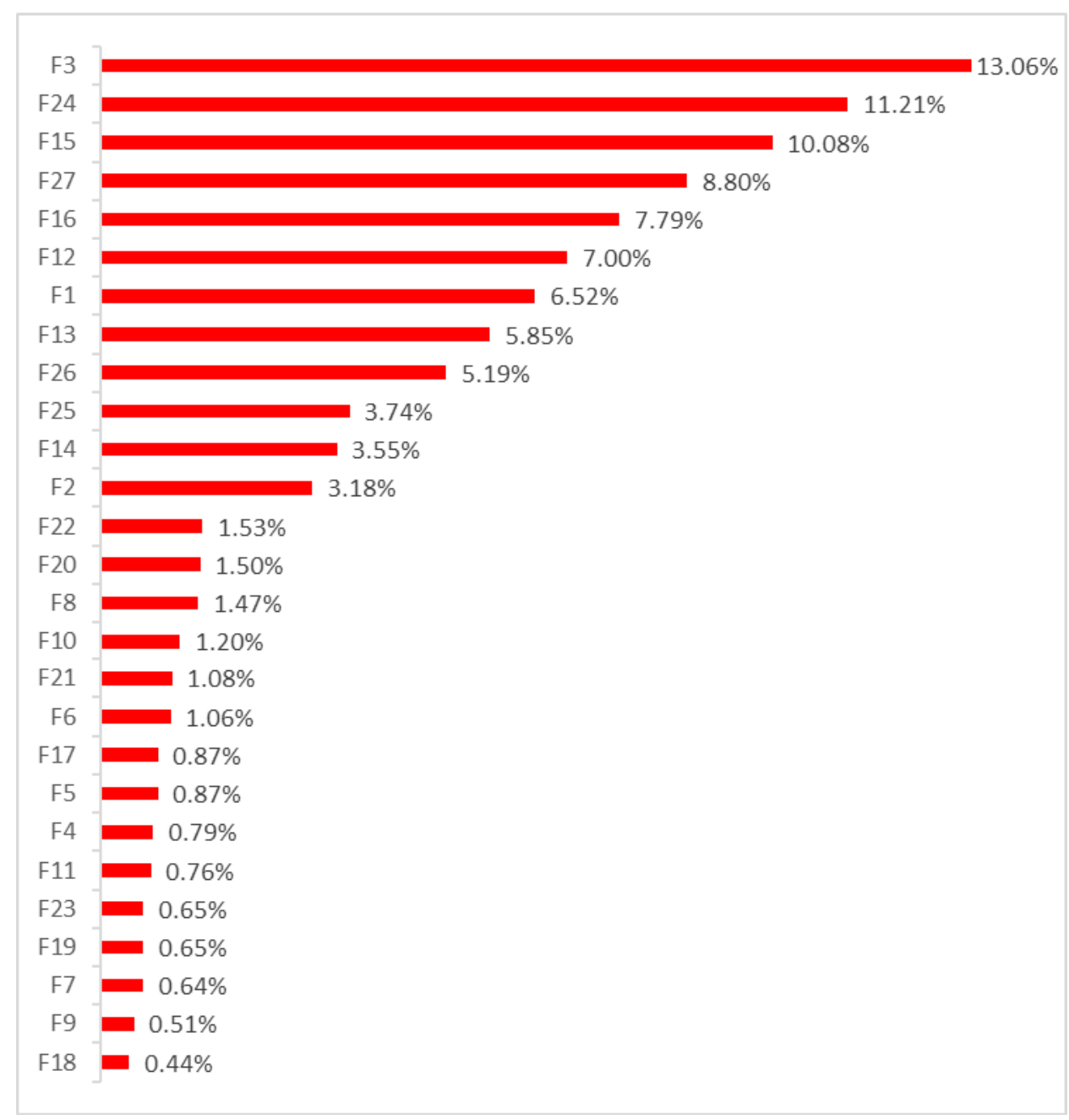

Figure 8. Overall hierarchy of factors determining the adoption of gasification.

Ranked in order of decreasing importance, the lack of spare parts at local and national level, the lack of available biomass, insufficient training of users, access to electricity in the zone where the technology is located, lack of involvement and coordination between the different stakeholders, lack of experience with gasification, the size of the equipment, lack of user awareness, non-industrial means of biomass transport and inaccessibility of biomass collection sites are the most important barriers to the adoption of gasification.

In the following section, these results are discussed based on the literature and in light of information resulting from the benchmarking analysis on pyrolysis technologies.

\section{Discussion}

Several barriers were identified that contributed to the failure of gasification. Using the AHP method, we ranked the barriers to identify the most significant ones. The pyrolysis benchmarking exercise revealed that these barriers are, conversely, the drivers of the success of pyrolysis. This biomass conversion technology, which is similar to gasification, has been 
a resounding success because its intrinsic attributes (comparative advantage, compatibility, complexity, adaptability and observation) are appropriate to the context in Burkina Faso. Interviews showed that when implementing pyrolysis, its promoters were inspired by the failure of gasification. The adoption of pyrolysis was favored thanks to the relatively low initial cost and the short three-month payback period. This helped to reassure investors and to create a bond of confidence between project leaders and beneficiaries. The availability of information on its operation and management, the training and supervision of users, the availability and accessibility of spare parts, the involvement of the actors of the design of the project were also drivers of the success of pyrolysis. In addition, the proven reliability of the pilot pyrolysis and easy access to biomass guided all the following cases. The fact that pyrolysis still works is partly due to the accessibility and availability of large quantities of cashew nut shells which have no other use as crop residues. The success of pyrolysis thus helped to better identify the key barriers to gasification deployment. Several studies have identified similar barriers, although they placed little emphasis on their prioritization, as required by the AHP method [23]. Information, for example, a description of the biomass, processing techniques and operating parameters of gas generators is often not available in a language that Burkinabe users can understand. In addition, Burkinabe users are not trained to use the machines, and information on product specifications, maintenance costs and technology costs is still not available in the public domain. This limits the long-term acceptance of gasification. The lack of awareness makes it difficult to promote gasification, as is the case in the Netherlands [47]. Additionally, the low income obtained by industries in Burkina Faso may reduce their enthusiasm for acquiring expensive technologies. The technology was introduced based on how to manage industrial waste and not on a real need for the technology by the population [23]. The success of an innovation is achieved through the combination of several technology packages (social, economic, organizational), as was the case of pyrolysis, where, in addition to the economic benefits of heat production, the by-products, mainly coal, are used as fuel by women employed in industries concerned.

Despite disruptions in state management of the country, highlighted by social crises in recent years, political barriers play a less important role. As gasification is still being tested and was introduced by projects, the government has had very little involvement in its dissemination. This echoes results obtained in Latin America, where despite favorable policies for the development of renewable energies, gasification has failed. Profitability compared to that of older techniques and long payback time are the main barriers to the adoption of the technology. This can be explained by the fact that the profit generated by any technology plays a significant role in encouraging users. The introduction of gasification requires high investment for installation, and long-term maintenance [23]. However, in Burkina Faso, this cost turned out to be one of the least important determinants of the adoption of gasification in the prevailing context. This was attributed to the contribution of donors in the implementation of the technology, which covered purchase of the equipment and the payment of salaries. However, this form of subsidy is often linked with a tendency to rely on assistance, which hinders the appropriation of operating accounts and consequently undermines the sustainability of the gasification technology.

\section{Conclusions}

Gasification is a promising solution to cover the need for heat and power of industries. However, it remains a complex and immature technology in Burkina Faso. This article identifies the key factors that may be blocking the adoption of biomass gasification. A total of 27 factors were identified and prioritized in 5 categories using the AHP method. Socio-cultural and organizational factors, and ecological and geographical factors were identified as the key determinants of the adoption of biomass gasification. These factors require more attention if the technology is to be revived and accepted. Adopting any technology or innovation can be facilitated by adequate training and an approach that includes all the stakeholders involved. Internal factors, especially technical ones, could be readapted or modified according to the needs and aspirations of users. 
On the other hand, changing the extrinsic environment of gasification, such as the individual or collective behavior of the stakeholders, requires years or even generations. The technology should be further promoted by trying to emulate successful cases. Once the "socio-cultural and organizational" category has been eliminated, there is a good chance of eliminating other categories of barriers that may influence the adoption of the gasification technology.

For the successful deployment of gasification in the Burkinabe context, it is crucial to conduct further investigations into how to give added value to by-products such as the ash left from the processed biomass. Nonetheless, the findings of this study will interest both development project coordinators and researchers and will be of practical use for both government and industry. The approach used will therefore help decision makers to consider the barriers highlighted there in the decision process for gasification technologies implementation. The approach can also be extended to the adoption of the renewable energies in African context.

The AHP method is one of the most popular and widely employed multicriteria decision making methods. Its approach is suitable for many decision-making problems. In the current study, it was used to identify of the key barriers of gasification technology. This can contribute to the revitalization of the gasification sector in Burkina Faso and to the improvement of the environment. Nevertheless, the approach has limitations related to the subjective nature of the modelling process. The pairwise comparison matrices were constructed based on the opinions of energy and gasification experts. These opinions are relative to the expert's background. As such, they may be biased. Some other methods such as ELECTRE methods can be combined to AHP in order to integrate quantitative data such as the cost of the biomass and the technology.

Author Contributions: Conceptualization: F.B., M.S., M.B., I.W.K.O. and T.D.; methodology: F.B., M.S., M.B., I.W.K.O. and T.D.; validation, M.S., M.B., I.W.K.O. and T.D.; formal analysis, F.B.; survey, F.B., M.S., M.B. and I.W.K.O.; data conservation, F.B.; preparation of the original draft: F.B.; revision and editing of the writing: F.B., M.S., M.B., I.W.K.O. and T.D.; supervision: M.S., M.B., I.W.K.O. and T.D. All authors have read and agreed to the published version of the manuscript.

Funding: This research was supported by the "Académie de Recherche et de l'Enseignement Supérieur de la Fédération Wallonie Bruxelles (Belgium), Commission de la Coopération au Développement (ARES CCD)" in the framework of an international research and development project "contribution to the satisfaction of energy needs in rural area by gasification of agricultural by-products", PRD2017 $2022^{\prime \prime}$.

Institutional Review Board Statement: Not applicable.

Informed Consent Statement: Not applicable.

Data Availability Statement: Not applicable.

Conflicts of Interest: The authors have no conflict of interest to declare.

\section{References}

1. Beck, S.; Ribon, O.; Rieding, N. Chiffres clés de l'énergie Édition. Epsilon 2020, 2020, 1-80.

2. Diedhiou, A.; Ndiaye, L.; Bensakhria, A.; Sock, O. Thermochemical conversion of cashew nut shells, palm nut shells and peanut shells char with $\mathrm{CO}_{2}$ and/or and/or steam to aliment a clay brick fi ring unit. Renew. Energy 2019, 142, 581-590. [CrossRef]

3. Zulqarnain; Ayoub, M.; Yusoff, M.H.M.; Nazir, M.H.; Zahid, I.; Ameen, M.; Sher, F.; Floresyona, D.; Budi Nursanto, E. A comprehensive review on oil extraction and biodiesel production technologies. Sustainability 2021, 13, 788. [CrossRef]

4. Yaqoob, H.; Teoh, Y.H.; Jamil, M.A.; Rasheed, T.; Sher, F. An experimental investigation on tribological behaviour of tire-derived pyrolysis oil blended with biodiesel fuel. Sustainability 2020, 12, 9975. [CrossRef]

5. Bhattacharya, S.C. Commercialisation options for biomass energy technologies in ESCAP countries. Int. J. Energy Technol. Policy 2003, 1, 363-399. [CrossRef]

6. Al-Juboori, O.; Sher, F.; Khalid, U.; Niazi, M.B.K.; Chen, G.Z. Electrochemical Production of Sustainable Hydrocarbon Fuels from CO2 Co-electrolysis in Eutectic Molten Melts. ACS Sustain. Chem. Eng. 2020, 8, 12877-12890. [CrossRef] 
7. Berahab, R. Energies Renouvelables en Afrique: Enjeux, défis et Opportunités. 2019, pp. 1-36. Available online: https://www.africaportal.org/publications/energies-renouvelables-en-afrique-enjeux-d\%C3\%A9fis-et-opportunit\%C3 \%A9s-renewable-energy-africa-issues-challenges-and-opportunities / (accessed on 2 May 2019).

8. Secrétariat Permanent de la Coordination des Politiques Sectorielles Agricoles. Deuxième Programme National du Secteur Rural (PNSR) 2016-2020; Secrétariat Permanent de la Coordination des Politiques Sectorielles Agricoles: Ouagadougou, Burkina Faso, 2017.

9. Louvel, R.; Gromard, C. De la biomasse à la bioéconomie, une stratégie énergétique pour l'Afrique? Afr. Contemp. 2017, 261-262, 223-240. [CrossRef]

10. Kwofie, E.M.; Ngadi, M. A review of rice parboiling systems, energy supply, and consumption. Renew. Sustain. Energy Rev. 2017, 72, 465-472. [CrossRef]

11. Patel, M.; Zhang, X.; Kumar, A. Techno-economic and life cycle assessment on lignocellulosic biomass thermochemical conversion technologies: A review. Renew. Sustain. Energy Rev. 2016, 53, 1486-1499. [CrossRef]

12. Höök, M.; Tang, X. Depletion of fossil fuels and anthropogenic climate change-A review. Energy Policy 2013, 52, 797-809. [CrossRef]

13. Sher, F.; Yaqoob, A.; Saeed, F.; Zhang, S.; Jahan, Z.; Klemeš, J.J. Torrefied biomass fuels as a renewable alternative to coal in co-firing for power generation. Energy 2020, 209, 13. [CrossRef]

14. Basu, P. Biomass Gasification, Pyrolysis and Torrefaction. Practical Design and Theory; Academic Press: Cambridge, MA, USA, 2013.

15. Makwana, J.P.; Pandey, J.; Mishra, G. Improving the properties of producer gas using high temperature gasification of rice husk in a pilot scale fluidized bed gasifier (FBG). Renew. Energy 2018. [CrossRef]

16. Giuliano, A.; Freda, C.; Catizzone, E. Techno-economic assessment of bio-syngas production for methanol synthesis: A focus on the water-gas shift and carbon capture sections. Bioengineering 2020, 7, 70. [CrossRef] [PubMed]

17. Alauddin, Z.A.B.Z.; Lahijani, P.; Mohammadi, M.; Mohamed, A.R. Gasification of lignocellulosic biomass in fluidized beds for renewable energy development: A review. Renew. Sustain. Energy Rev. 2010, 14, 2852-2862. [CrossRef]

18. Tanger, P.; Field, J.L.; Jahn, C.E.; Defoort, M.W.; Leach, J.E.; Allison, G.G. Biomass for thermochemical conversion: Targets and challenges. Front. Plant Sci. 2013, 4, 1-20. [CrossRef]

19. Chang, J.; Leung, D.Y.C.; Wu, C.Z.; Yuan, Z.H. A review on the energy production, consumption, and prospect of renewable energy in China. Renew. Sustain. Energy Rev. 2003, 7, 453-468. [CrossRef]

20. Chang, Q.; Zhuo, S.; Meng, J.; Qin, S.; Yao, S. Clean coal technologies in China: Current status and future perspectives. Engineering 2016, 2, 447-459. [CrossRef]

21. Brew-Hammond, A.; Kemausuor, F. Guidebook on Modern Bioenergy Conversion Technologies in Africa; UNIDO: Vienna, Austria, 2008.

22. Zhang, Z.; Chen, B.; Chen, A.; Zhao, W. Barriers to commercialization development of crop straw gasification technology in China and promoting policy design. Energy Sources Part B Econ. Plan. Policy 2013, 8, 279-289. [CrossRef]

23. Sansaniwal, S.K.; Rosen, M.A.; Tyagi, S.K. Global challenges in the sustainable development of biomass gasification: An overview. Renew. Sustain. Energy Rev. 2017, 80, 23-43. [CrossRef]

24. Akbi, A. Les politiques de soutien aux biocarburants. CREDEN 2017, 33, 1-45.

25. Dasappa, S.; Sridhar, H.V.; Sridhar, G.; Paul, P.J.; Mukunda, H.S. Biomass gasification-A substitute to fossil fuel for heat application. Biomass Bioenergy 2003, 25, 637-649. [CrossRef]

26. Dai, J.; Cui, H.; Grace, J.R. Biomass feeding for thermochemical reactors. Prog. Energy Combust. Sci. 2012, 38, 716-736. [CrossRef]

27. Buragohain, B.; Mahanta, P.; Moholkar, V.S. Biomass gasification for decentralized power generation: The Indian perspective. Renew. Sustain. Energy Rev. 2010, 14, 73-92. [CrossRef]

28. Díaz González, C.A.; Pacheco Sandoval, L. Sustainability aspects of biomass gasification systems for small power generation. Renew. Sustain. Energy Rev. 2020, 134. [CrossRef]

29. Saidou, A.L. Caractérisation des Performances d'une Unité Pilote de Gazéification de Biomasse: Analyse de Faisabilité Technique, Économique et Environnementale pour une Utilisation Chez un Artisan D'une Filière Agroalimentaire au Burkina; Institut International d'Ingénierie de l'Eau et de l'Environnement: Ouagadougou, Burkina Faso, 2013; p. 83.

30. Chidikofan, G.F. Développement Méthodologique pour L'évaluation des Performances et de la Durabilité de Systèmes de Production D'électricité par Gazéification de Biomasse en Milieu Rural. Etude de cas au Burkina Faso; Institut International d'Ingénierie de l'Eau et de l'Environnement (2iE)/Energie, Ouagadougou en cotutelle avec École Nationale Supérieur d'Arts et Metiers/Génie Energétique: Paris, France, 2017.

31. Ettorchi-Tardy, A.; Levif, M.; Michel, P. Le benchmarking: Une méthode d'amélioration continue de la qualité en santé. Prat. Organ. Soins 2011, 42, 35-46. [CrossRef]

32. Abu-Taha, R.; Daim, T. Multi-criteria applications in renewable energy analysis, a literature review. Res. Technol. Manag. Electr. Ind. Green Energy Technol. 2013, 60, 17-31.

33. Gunduz, M.; Almuajebh, M. Critical success factors for sustainable construction project management. Sustainability 2020, 12, 1990. [CrossRef]

34. Hamurcu, M.; Eren, T. Strategic planning based on sustainability for urban transportation: An application to decision-making. Sustainability 2020, 12, 3589. [CrossRef] 
35. Bukari, D.; Kemausuor, F.; Quansah, D.A.; Adaramola, M.S. Towards accelerating the Deployment of decentralised renewable energy mini-grids in Ghana: Review and analysis of barriers. Renew. Sustain. Energy Rev. 2021, 135, 110408. [CrossRef]

36. Numata, M.; Sugiyama, M.; Mogi, G. Barrier Analysis for the Deployment of Renewable-Based Mini-Grids in Myanmar Using the Analytic Hierarchy Process (AHP). Energies 2020, 13, 1400. [CrossRef]

37. Karatayev, M.; Hall, S.; Kalyuzhnova, Y.; Clarke, M.L. Renewable energy technology uptake in Kazakhstan: Policy drivers and barriers in a transitional economy. Renew. Sustain. Energy Rev. 2016, 66, 120-136. [CrossRef]

38. Ghimire, L.P.; Kim, Y. An analysis on barriers to renewable energy development in the context of Nepal using AHP. Renew. Energy 2018, 129, 446-456. [CrossRef]

39. Luthra, S.; Kumar, S.; Garg, D.; Haleem, A. Barriers to renewable/sustainable energy technologies adoption: Indian perspective. Renew. Sustain. Energy Rev. 2015, 41, 762-776. [CrossRef]

40. Saaty, T.L. Decision making with the analytic hierarchy process. Int. J. Serv. Sci. 2008, 1, 83-98. [CrossRef]

41. Saaty, T.L. Fundamentals of the Analytic Hierarchy Process. In The Analytic Hierarchy Process in Natural Resource and Environmental Decision Making; Springer: Dordrecht, The Netherlands, 2001; pp. 15-35.

42. Chang, C.W.; Wu, C.R.; Lin, C.T.; Chen, H.C. An application of AHP and sensitivity analysis for selecting the best slicing machine. Comput. Ind. Eng. 2007, 52, 296-307. [CrossRef]

43. Saaty, T. Fundamentals of Decision Making and Priority Theory, 2nd ed.; RWS Publications: Pittsburgh, PA, USA, 2000.

44. Saaty, T.L.; Kearns, K.P. Analytical Planning: The Organization of System; Pergamon Press: New York, NY, USA, 1985.

45. Keeley, A.R.; Matsumoto, K. Relative significance of determinants of foreign direct investment in wind and solar energy in developing countries-AHP analysis. Energy Policy 2018, 123, 337-348. [CrossRef]

46. Caupin, V.; Gravellini, J.-M.; Périou, C. L'action des bailleurs de fonds pour soutenir le développement financier en afrique: Le cas de l'agence française de développement. Rev. D'économie Financ. 2014, 4, 177-192. [CrossRef]

47. Negro, S.O. Dynamics of Technological Innovation Systems: The Case of Biomass Energy; Copernicus Institute for Sustainable Development and Innovation: Utrecht, The Netherlands, 2007. 